MOLECULAR AND CELL BIOTECHNOLOGIES

\title{
Construction of vectors for plant transformation to confer resistance to potyviruses
}

\author{
I. V. Korniichuk, V. P. Polischuk, S. D. Yeh ${ }^{1}$
}

\author{
National Taras Shevchenko University of Kyiv, \\ 64, Volodymyrska street, 01033 Kyiv, Ukraine \\ ${ }^{1}$ National Chung Hsing University \\ 250, Kuo Kuang Rd., Taichung 402, Taiwan \\ taiwan06@mail.ru \\ inna_korniichuk@mail.ru
}

\begin{abstract}
Genes HC-Pro, CIP, NIb, and CP are known to be the most conservative in genome of the potyviruses. The comparison of nucleotide sequences of these genes for 32 viruses of Potyvirus genus was carried out. The fragments with the highest percent of identity were selected, amplified from full size cDNA of Turnip mosaic virus (TuMV), and inserted into a high-copy TOPO-vector, used for the transformation of competent E. coli cells. The construction of vectors for plant transformation on the basis of commercial vector $p B I 121$ was performed. cDNA corresponding to one separate (HC-Pro, CIP, NIb or CP), two (HC-Pro and CIP), and three (HC-Pro, CIP, and NIb) conservative regions was inserted into the vector. The transformed cells of A. tumefaciens carrying plasmids pBI121 were obtained.
\end{abstract}

Keywords: vector, cloned DNA (cDNA), Polymerase Chain Reaction (PCR), transformation, restriction analysis

Introduction. Potyviruses, in particular - genus Potyvirus, cause serious diseases in plants in all climatic zones of the Earth, including Europe, Africa, Asia, Oceania, North and South Americas [1]. Nowadays there are physical, agrotechnical, biological, and chemical approaches to fighting potyvirus infections of plants. However, regardless of wide application, these approaches did not reveal sufficient efficiency as they are not able to provide the complete elimination of virus from plant organism [2].

(C) I. V. KORNIICHUK, V. P. POLISCHUK, S. D. YEH, 2007
Since the presentation of the concept of pathogen-induced resistance (PIR) in 1985 [3], the direction of searching the ways for relieving the plants of viruses shifted towards the formation of transgenic plants, resistant to the mentioned pathogens. Currently, there are numbers of genetically modified plants, possessing genome regions of viruses and demonstrating high resistance to the effect of the latter [4-6]. One of the ways of obtaining this sort of resistance is the development of transgenic plants on the basis of RNA-dependant silencing of genes, which, at the condition of natural environment, is one of the most important mechanisms of 
plant protection [7-9]. This post transcriptional process is initiated by molecules of double-stranded RNA and results in degradation of complementary RNA [10, 11].

The application of transformation of plants using Agrobacterium tumefaciens allowed obtaining a number of plants with high resistance to potyviruses [12, 13]. However, most of the experiments were aimed at the application of certain genes to enable the resistance [14-16], which turned out to be rather long-lasting, yet it was disadvantageous for the possibility to be overcome by other virus strains, i.e. narrow range resistance. Minding the aforementioned, important task of today is the development of wide range resistance to numerous strains and types of viruses $[5,17,18]$.

Current work was aimed at the construction of transformation vectors, containing one, two, or three conservative regions of potyvirus genome in order to compare obtained resistance of plants to Potyvirus representatives.

Materials and Methods. Selection of conservative regions of potyviral genome. The comparison of nucleotide sequences of HC-Pro, CIP, NIb, and CP genes of 32 Potyvirus viruses using Bioedit software (www.mbio.ncsu.edu/BioEdit/bioedit.html) and DNAStar (www.dnastar.com) allowed selecting conservative fragments on the basis of percentage of identity and the presence of important functional regions.

Viral $c D N A$. Full-length cDNA of Turnip mosaic virus (TuMV) was used as a source of DNA regions for incorporation into the vectors for transformation of plants.

Amplification of fragments. Amplification of conservative regions of genes HC-Pro (505 nt), CIP (620 nt), NIb (580 nt), and CP (455 nt) with TuMV cDNA was performed by PCR (denaturation -1 cycle: $95^{\circ} \mathrm{C} / 5$ min; annealing -30 cycles: $95^{\circ} \mathrm{C} / 30 \mathrm{sec}, 58^{\circ} \mathrm{C} / 30 \mathrm{sec}$, $72^{\circ} \mathrm{C} / 30 \mathrm{sec}$; elongation -1 cycle: $72^{\circ} \mathrm{C} / 5 \mathrm{~min}$ ). To amplify HC-Pro fragment, two primers were used, namely pTuHCXbaI (5'-GCTCTAGATAATAATAACAGTCGAGTGTG$\left.3^{\prime}\right)$, containing $X b a I$ restriction site and two TAA stop-codons, and mTuHCSacIXhoIKpnI (5'-CGAGCTCCTCGAGGGTACCGTGAATTTGTG AGTTG-3'), containing restriction sites for SacI, Xhol, and KpnI. Amplification of conservative region of CIP gene was carried out using pTuCIPXbaIKpnI (5'-GCTCTAGAGGTACCTAATAAAGACATATT ACTAATGGG-3') primer, containing restriction sites for XhaI and Kpn and two stop-codons, and mTuCIPXhoIPacI

(5'-CCCTCGAGTTAATAAACCAACTTTCATCGT

TATT-3'), containing restriction sites for XhoI and PacI. To amplify NIb, the following primers were used: $p T u N I b P a c I$ (5'-CCTTAATTAATAATAACCTAGGAAAGATG GGAG-3'), containing PacI restriction site and two stop-codons, and mTuNIbXhoISalI (5'-CCCTCGAGGTCGACAATCATCTCCGTTGAC G-3'), containing restriction sites for XhoI and SalI. Amplification of conservative region of $C P$ gene was carried out using $p T u C P A v r I I S a l I$ (5'-CCCCTAGGGTCGACTAATAAAATGGTTTAA TGGTCTGG-3') primer, containing restriction sites for AvrII and SalI and two stop-codons, and mTuCPXhoI (5'-CCCTCGAGAACGCCCAGTAAGTAATG-3'), containing XhoI restriction site.

TOPO-cloning and verification of the presence of fragments in TOPO-vector. TOPO-cloning of the amplified cDNA fragments was carried out using a commercially available multicopy PCR 2.1-TOPO vector (Invitrogen, USA), $3.91 \cdot 10^{3} \mathrm{nt}$ long, in accordance to the protocol (www.invitrogen.com). Vector-transformed Escherichia coli cells were incubated in LB medium ( $1 \%$ trypton, $0.5 \%$ yeast extract, $0.5 \mathrm{NaCl})$ for 1 hour at $37^{\circ} \mathrm{C}$. After incubation, E. coli cells were inoculated onto LA selective medium (LB, $1.5 \%$ agar) with IPTG (isopropyl- $\beta$-D-tiogalactopyranoside) and X-gal (5-bromine-4-chlo-

rine-3-indole- $\beta$-D-galactopyranoside). Eight separate colonies were taken from each Petri dish to verify the presence of HC-Pro, eight colonies for $C P$, two colonies for $C I P$ and five colonies for NIb. Selected colonies were incubated in $1 \mathrm{ml} \mathrm{LB}$ for 8 hours at $37^{\circ} \mathrm{C}$. $E$. coli cells were centrifuged for $1 \mathrm{~min}$ at $1000 \mathrm{~g}$, then supernatant was extracted and the sediment was added $300 \mu \mathrm{l}$ of TENS solution (TE-buffer, $0.1 \mathrm{~N} \mathrm{NaOH}$, $0.5 \%$ SDS). After slight stirring, the solution was added $150 \mu \mathrm{l}$ of $\mathrm{NaOAc}$ and centrifuged for $2 \mathrm{~min}$ at $5000 \mathrm{~g}$. Then supernatant was added $900 \mu \mathrm{l}$ of $100 \%$ ethanol and centrifuged for $2 \mathrm{~min}$ at $10000 \mathrm{~g}$. $100 \%$ $\mathrm{C}_{2} \mathrm{H}_{5} \mathrm{OH}$ was removed and then $900 \mu$ l of cold $80 \%$ eth- 
anol were added. After removal of $80 \%$ ethanol, micro tubes were dried in air. Then micro tubes were added 50 $\mu l$ of distilled water and stirred in order to dissolve DNA.

Isolated plasmid DNA was used for amplification. The sequence of fragments was also checked using automatic DNA sequencing system (Applied Biosystems, USA).

Cloning of $p$ BI121. cDNA fragments of conservative regions of $\mathrm{HC}$-Pro, $C I P$, NIb, and $C P$ genes were cut out with TOPO-vector and corresponding restrictases. To obtain the structure with one conservative region fragments $\mathrm{HC}$-Pro, CIP, NIb, and $C P$ were cut with $X b a I$ and $X h o I$ enzymes. To construct the plasmids with two regions, HC-Pro and $C I P$ were cut using $\mathrm{XbaI} / \mathrm{KpnI}$ and $\mathrm{KpnI} / \mathrm{XhoI}$ enzymes. To obtain the strucutre with three conservative regions, HC-Pro, CIP, and NIb were split with XbaI/KpnI, Kpn I/PacI, and PacII/XhoI restrictases, respectively. GUS gene was cut out of commercial vector for transformation of $\mathrm{pBI} 121$ plants using restrictases $\mathrm{XbaI}$ and XhoI.

Electrophoresis of restriction products was performed in $1.2 \%$ agarose gel. Fragments, corresponding to the sizes of HC-Pro, $C I P, N I b$, and $C P$ regions as well as vector $p B I 121$ were cut out of gel and eluted using Micro Elute DNA Clean/Extraction Kit (Genmark, Taiwan). Elution products were examined for the presence of DNA fragments by electrophoresis in $0.8 \%$ agarose gel.

The regions were inserted into $p B I 121$ vector by ligation with Fast-Link DNA ligase (Epicentre, USA). To obtain the structure with one fragment of cDNA of conservative regions, $\mathrm{HC}$-Pro, $\mathrm{CIP}, \mathrm{NIb}$, or $C$ were separately inserted into $p B I 121$. To obtain $p B I 121$ with two regions, HC-Pro and CIP were inserted into $p B I 121$, and to obtain the structure with three bound regions in the vector, HC-Pro, CIP, and NIb were added together to the ligation mixture. The mixture was added the vector and fragments (1:3 ratio), $2 \mu 110 \times$ ligation buffer, $1 \mu \mathrm{l}$ of $25 \mathrm{mM} \mathrm{ATP}, 1 \mu \mathrm{DNA}$-ligase, $12 \mu \mathrm{l}$ of distilled water. The mixture was incubated at $16^{\circ} \mathrm{C}$ for 8 hours. Competent E. coli cells were transformed with $15 \mu \mathrm{l}$ of ligation product using the method of chemical transformation [13, 19] and inoculated onto LA medim with kanamycin $(50 \mathrm{mg} / \mathrm{l})$.
Screening of E. coli cells for presence of plasmids, containing cDNA of potyvirus genes. Six E. coli colonies were selected from each Petri dish. Selected colonies were incubated in $5 \mathrm{ml}$ of LB medium at $37^{\circ} \mathrm{C}$ for 8 hours. Plasmid DNA was isolated using Plasmid miniprep purification Kit (Hopegen Biotechnology Enterprise, Taiwan). Fragments $\mathrm{HC}$-Pro, $\mathrm{CIP}, \mathrm{NIb}, \mathrm{CP}$, $H C-C I P$, and $H C-C I P-N I b$ were amplified by PCR. Restriction analysis was performed with $\mathrm{XbaI}$ and $\mathrm{XhoI}$ restrictases. Restriction products were examined by electrophoresis in $0.8 \%$ agarose gel.

Transformation of A. tumefaciens using pBI121 plasmid. A. tumefaciens cells were incubated in $50 \mu \mathrm{l}$ of LB medium with $5 \mu 1$ of streptomycin $(50 \mathrm{mg} / \mathrm{l})$ at $28^{\circ} \mathrm{C}$ for 8 hours till $\mathrm{CD}_{60}=0.5$. The cells were precipitated by centrifuging at $5000 \mathrm{~g}\left(5 \mathrm{~min}, 4^{\circ} \mathrm{C}\right)$. The sediment was dissolved in $10 \mathrm{ml}$ of $0.15 \mathrm{M} \mathrm{NaCl}$ and centrifuged at $5000 \mathrm{~g}\left(5 \mathrm{~min}, 4^{\circ} \mathrm{C}\right)$. The sediment was dissolved in $1 \mathrm{ml}$ of cold $20 \mathrm{mM} \mathrm{CaCl}_{2}$. $0.2 \mathrm{ml}$ of suspension was transferred into new micro tubes and added $1 \mu 1$ of plasmid DNA, isolated from E. coli. Micro tubes were placed into container with liquid nitrogen for $1 \mathrm{~min}$, and then incubated at $28^{\circ} \mathrm{C}$ for $2-4$ hours. A. tumefaciens cells were inoculated onto LA medium with kanamycin $(50 \mathrm{mg} / \mathrm{l})$ and incubated at $28^{\circ} \mathrm{C}$ for $2-3$ days.

Verification of A. tumefaciens cells for the presence of plasmids with one, two, and three conservative regions. Plasmid DNA was isolated from specific bacterial colonies of $A$. tumefaciens. The regions of HC-Pro, $C I P, N I b, C P, H C-C I P$, and HC-CIP-NIb were amplified using PCR. Plasmids, isolated from E. coli cells, were selected as control.

Results and Discussion. The efficiency of process of RNA-dependant silencing of genes - the milestone of resistance of transgenic plants - is determined as the percentage of complementarity between RNA of virus and DNA of transgene. Effective process of inactivation of virus RNA is achieved at $50+\%$ of the number of complementary bases $[19,20]$. Thus, in order to construct vectors, the primary task was to discover and to select the most conservative regions in genomes of 32 potyviruses, with the purpose of increasing the possibility of complementary binding with transgenic DNA. The level of homology of 5'- and 3'-terminal ends of potyvirus genes $P 1, P 2$, and NIa is less than $50 \%$ [1]. We carried out the comparative analysis of nucleotide 


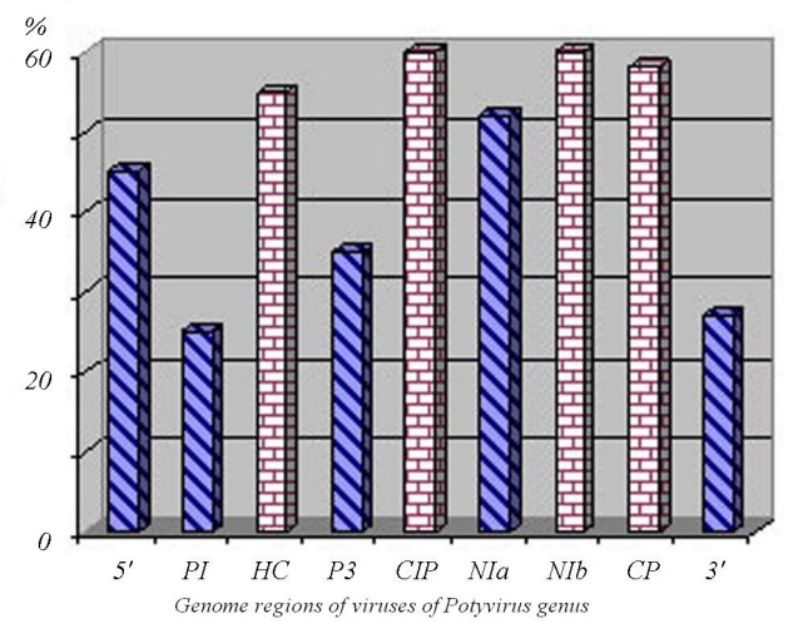

Fig.1 Level of homology between nucleotide sequences of genome regions of 32 viruses of Potyvirus genus, 1 - literature data; 2 - results, obtained by us with positive RNA-genome [21]. $C P$ region contained highly conservative fragment of five codons, which was shown for tobacco etch virus to be responsible for replication of potyviruses [11]. The mentioned fragments were amplified from full-length TuMV cDNA using PCR. The results of amplification reveal the presence of fragments, corresponding to the sizes of conservative regions (Fig.2, $a$ ).

PCR products were incorporated into TOPO-vector and transformed into competent $E$. coli cells. The latter were inoculated onto LA medium with the inductor of transcription of vector gene of IPTG galactosidase and the product for splitting using X-gal enzyme. During the insertion of PCR-product into the region of galactosidase (1acZ) in Topo-vector, enzyme-encoding gene was broken and therefore, was neither transcribed
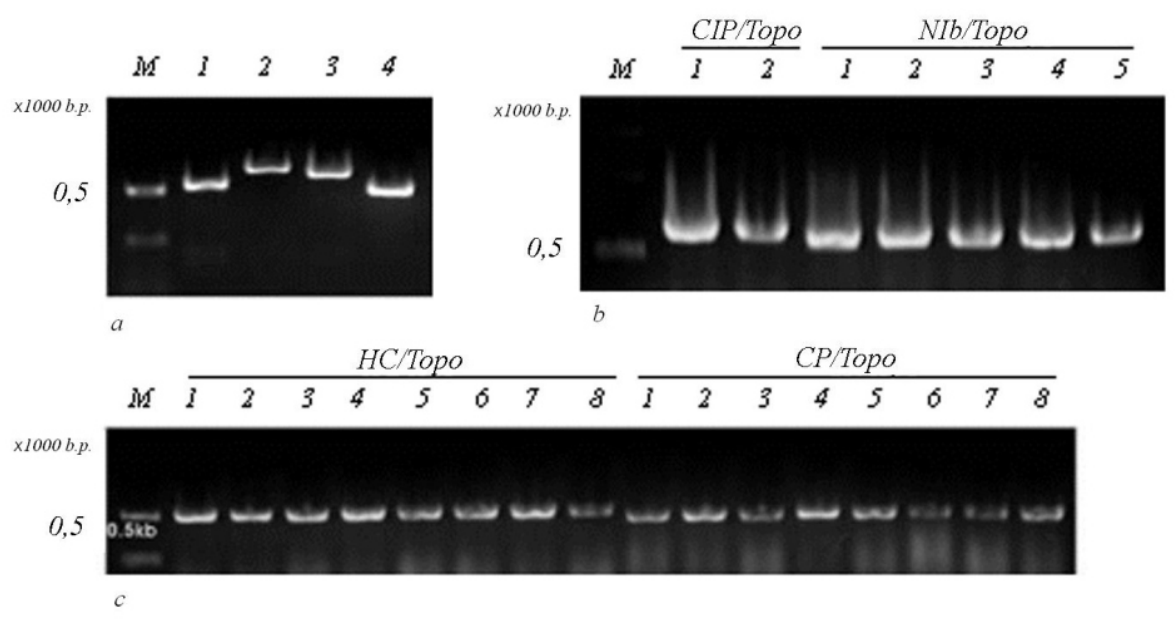

Fig. 2 Electrophoregrams of amplification products of HC-Pro (1), CIP (2), NIb (3), $C P(4)$ with full length TuMV cDNA $(a)$ and amplification products of $C I P, N I b(b)$ and $H C$-Pro, $C P(c)$ from TOPO-vector (band number corresponds to the samples of certain colonies, see text for explanation)

sequences of the following genes: HC-Pro, CIP, NIb, and $C P$ of Potyvirus viruses. These genes revealed the level of homology to be higher than 50\% (Fig.1). The selection of conservative fragments depended heavily on the presence of regions, responsible for vital functions of the virus. Thus, amino acid sequence of HC-Pro conservative region contained $\mathrm{CC} / \mathrm{SC}$ motif, responsible for the replication and systemic motion of the virus, and RNA region, necessary for the transfer by plant louses. Conservative region in amino acid sequence of CIP gene contains nucleotide-binding region of CxxCxxGKS, specific for many helicases [1]. NIb fragment contained three (I, II, and III) of eight regions, conservative among all RNA-polymerases of viruses nor translated. Thus, cells, containing Topo-vector, are not capable of synthesizing galactosidase and of splitting the substrate. Consequently, they formed white colonies vs. blue colonies in which X-gal interacted with the enzyme. To verify the presence of inserted fragments, five different colonies were selected for amplification of incorporated regions by PCR among eight white colonies from lawn of $E$. coli cells, transformed with $H C /$ Topo and $C P / T o p o$; two colonies from lawn of E. coli cells, transformed with CIP/Topo, and two colonies from lawn of E. coli cells, containing NIb/Topo. The results of amplification revealed the presence of fragments in Topo-vector, with their sizes corresponding to the size of each conservative region (Fig.2, $b$ ). 


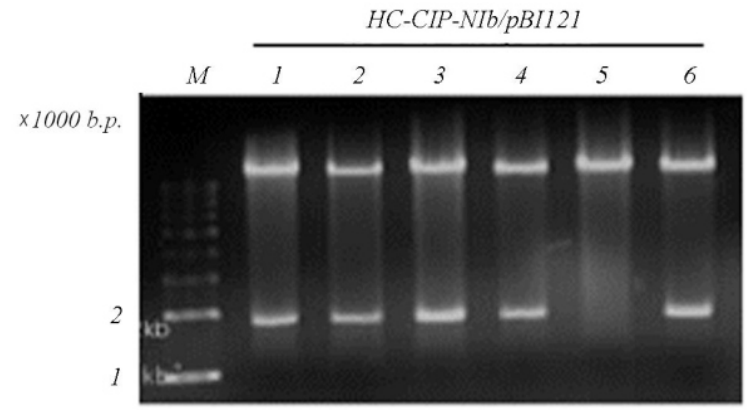

Fig.3 Electrophoresis of restriction products for determination of the presence of $H C$-CIP-NIb in $p B I 121$ (band number corresponds to the samples of certain colonies, see text for explanation)

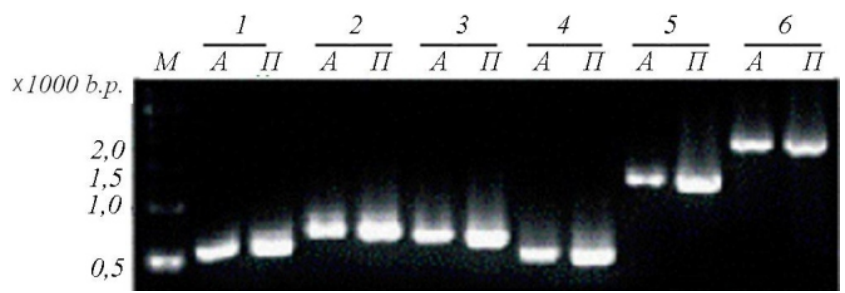

Fig.4 Electrophoregram of results of PCR for the presence of HC-Pro (1), CIP (2), NIb (3), CP(4), HC-CIP (5), HC-CIP-NIb (6) in A. tumefaciens and in plasmid containing $E$. coli, respectively

Vector for transformation of plants $p B I 121,14 \cdot 10^{3} \mathrm{nu}-$ cleotides long, with selective marker of neomycin-phosphotransferase II (nptII), conditioning the resistance to kanamycin, was used. Beside nptII, pBI121 contained glucuronidase gene (GUS), which was substituted by conservative regions.

The fragments were cut out of Topo-vector, while GUS was cut out of $p B I 121$. cDNA of fragments and $p B I 121$ were cut out of agarose gel for electrophoresis and eluted.

To obtain the vector with one conservative region, certain fragments of $H C$-Pro, $C I P, N I b$, or $C P$ were inserted into the vector for transformation of $p B I 121$ plants. To obtain the plasmids with two fragments, $H C$-Pro and CIP were inserted into $p B I 121$. Block of fragments of $\mathrm{HC}$-Pro, CIP, and NIb were also inserted into plasmid to obtain the structure with three conservative regions. The presence of structure with three conservative regions in the vector was verified using restriction analysis. For this purpose, six colonies of $E$. coli cells, transformed with $H C-C I P-N I b / p B I 121$ were selected. Thus, the presence of DNA regions with cor- responding size of fragments has been determined (Fig.3).

Transformation of competent $A$. tumefaciens cells was also subjected to PCR in order to analyse the presence of plasmids, containing conservative regions. The data obtained reveal the presence of vectors in $A$. tumefaciens cells, namely, $505 \mathrm{nt}$ for HC-Pro, $620 \mathrm{nt}$ for CIP, $580 \mathrm{nt}$ for NIb, 455 for $C P, 1125$ for block of fragments of HC-Pro and CIP, and 1705 for three bound regions of HC-Pro, CIP, and NIb (Fig.4).

Thus, we selected TuMV genes, which share the highest percentage of identity with 31 virus of Potyvirus genus. Conservative fragments of four potyvirus genes were selected taking into account the homology of nucleotide sequence and the presence of important functional regions.

Conclusions. We constructed the vectors, containing one conservative region of the genes HC-Pro, $C I P, N I b$, or $C P$ of Turnip mosaic virus. To compare the levels of acquired resistance of transgenic plants against potyviruses, multi-gene structures, containing two conservative regions $H C$-Pro and CIP for TuMV were obtained. We also developed vectors, containing three conservative fragments of $\mathrm{HC}$-Pro, $\mathrm{CIP}$, and $\mathrm{NIb}$ genes. One-, two-, three-gene structures were obtained in transformed $A$. tumefaciens cells.Створення векторів трансформації рослин для отримання стійкості до потівірусів

\section{И. В. Корнейчук, В. П. Полищук, Ш. Д. Йе}

Создание векторов трансформации растений для получения устойчивости к потивирусам

\section{Р е $з$ ю м е}

Наиболее консервативными среди всех участков генома потивирусов являются гены НC-Pro, CIP, NIb и CP. Проведено сравнение нуклеотидной последовательности данных генов у 32 вирусов рода Potyvirus и отобраны области, отличающиеся самым высоким процентом идентичности. Области амплифицировали с полноразмерной кДНК вируса мозаики турнепса (ВМТ) и встраивали в высококопийный ТОРО-вектор, которым трансформировали компетентные клетки Escherichia coli. Сконструированы векторы трансформации растений на основе коммерческой плазмиды рВI121, в которой встроены кДНК отдельно одного (HC-Pro, CIP, NIb или CP), двух (HC-Pro и CIP) $и$ трех (HC-Pro, CIP и NIb) консервативних участков генов BMT. Получены трансформированные клетки Agrobacterium tumefaciens, несущие pBI121.

Ключевые слова: потивирусы, резистентность, кДНК, ПЦР, трансформачия растений. 


\section{REFERENCES}

1. Baulcombe D. C. Mechanisms of Pathogen-derived resistance to viruses in transgenic plants // The Plant Cell.-1996.-8.P. 1833-1844.

2. Burch-Smith T. M., Schiff M., Liu Y., Dinesh-Kumar S. P. Efficient virus-induced gene silencing in Arabidopsis // Plant Physiol.-2006.-142.-P. 21-27.

3. Chumakov M. I. Transfer of genetic information from Agrobacteria to bacterial and plant cells: membrane and submembrane structures involved in transfer// Membrane Cell Biol.-2000.-14.-P. 309-331.

4. Di Nicola-Negri E. Hairpin RNA-mediated silencing of Plum pox virus $P I$ and $H C$-Pro genes for efficient and predictable resistance to the virus // Transgenic Res.-2005.-14.P. 989-994.

5. Fuchs M., Gonsalves D. Resistance of transgenic hybrid squash ZW-20 expressing the coat protein genes of Zuccini yellow mosaic virus and watermelon mosaic virus 2 to mixed infections by both potyviruses // BioTechnology.-1995.13.-P. 1466-1473.

6. Germudsson A., Valkonen J. P. PI- and VPg-transgenic plants show similar resistance to Potato virus $A$ and may compromise long distance movement of the virus in plant sections expressing RNA silencing-based resistance // Virus Res.-2006.-116.-P. 208-213.

7. Hily J. M. Stability of gene silencing-based resistance to Plum pox virus in transgenic plum (Prunus domestica L.) under field conditions // Transgenic Res.-2004.-13.P. 427-436.

8. Jan F. J., Fagoaga C., Pang S. Z., Gonsalves D. A single chimeric transgene derived from two distinct viruses confers multi-virus resistance in transgenic plants through homology-dependent gene silencing // J. Gen. Virol.-2004.81.-P. 2103-2109.

9. Komari T. Binary vectors and super-binary vectors // Meth. Mol. Biol.-2006.-343.-P. 15-41.

10. Koonin E. $V$. The phylogeny of RNA-dependent RNA polymerases of positive-strand RNA viruses // J. Gen. Virol.-1991.-11.-P. 2197-2206.

11. Mahajan S., Dolja V. V., Carrington J. C. Roles of the sequence encoding tobacco etch virus capsid protein in genome amplification: requirements for the translation process and a cis-active element // J. Virol.-1996.-70.P. 4370-4379.

12. Meynard J. M., Dore T., Lucas P. Agronomic approach: cropping systems and plant diseases // Cr. Biol.-2003.326.-P. 37-46.

13. Ratcliff F., Harrison B. D., Baulcombe D. C. A similarity between viral defense and gene silencing in plants // Science.-1997.-276.-P. 1558-1560.

14. Ravelonandro $M$. The use of transgenic fruit trees as a resistance strategy for virus epidemics: the plum pox (sharka) model // Virus Res.-2000.-71.-P. 63-69.

15. Rychahou P. G., Jackson L. N., Farrow B. J., Evers B. M. RNA interference: mechanisms of action and therapeutic consideration // Surgery.-2006.-140.-P. 719-725.

16. Sanford J. C., Johnson S. A. The concept of pathogen derived resistance: Deriving resistabce genes from the parasite's own genome // J. Theor. Biol.-1985.-113.P. 395-405.

17. Scorza $R$. Post-transcriptionl gene silencing in plum pox virus resistant transgenic European plum containing the plum pox virus coat protein gene // Transgenic Res.-2001.-10.P. 201-209.

18. Shukla D. D., Ward C. W., Brunt A. A. The Potyviridae / Ed. D. D. Shukla.-Wallingford: CAB Int., 1994.-P. 1-26.

19. Stram Y., Kuzntzova L. Inhibition of viruses by RNA interference // Virus Genes.-2006.-32.-P. 299-306.

20. Timmons L. Construction of plasmids for RNA interference and in vitro transcription of double-stranded RNA // Meth. Mol. Biol.-2006.-351.-P. 109-117.

21. Waterhouse P. M., Fusaro A. F. Plant science. Viruses face a double defense by plant small RNAs // Science.-2006.-313.-P. 54-55.
UDC 578.2

Received 26.02.07 